\title{
The Age of Effectors: Genome-Based Discovery and Applications
}

\author{
Hesham A. Y. Gibriel, Bart P. H. J. Thomma, and Michael F. Seidl
}

Laboratory of Phytopathology, Wageningen University, Droevendaalsesteeg 1, 6708 PB Wageningen, The Netherlands. Accepted for publication 29 March 2016.

\begin{abstract}
Gibriel, H. A. Y., Thomma, B. P. H. J., and Seidl, M. F. 2016. The age of effectors: Genome-based discovery and applications. Phytopathology 106:1206-1212.

Microbial pathogens cause devastating diseases on economically and ecologically important plant species, threatening global food security, and causing billions of dollars of losses annually. During the infection process, pathogens secrete so-called effectors that support host colonization, often by deregulating host immune responses. Over the last decades, much of the research on molecular plant-microbe interactions has focused on the identification and functional characterization of such effectors. The increasing

availability of sequenced plant pathogen genomes has enabled genomicsbased discovery of effector candidates. Nevertheless, identification of full plant pathogen effector repertoires is often hampered by erroneous gene annotation and the localization effector genes in genomic regions that are notoriously difficult to assemble. Here, we argue that recent advances in genome sequencing technologies, genome assembly, gene annotation, as well as effector identification methods hold promise to disclose complete and correct effector repertoires. This allows to exploit complete effector repertoires, and knowledge of their diversity within pathogen populations, to develop durable and sustainable resistance breeding strategies, disease control, and management of plant pathogens.
\end{abstract}

Plant-associated microbes, which include bacteria, fungi, oomycetes, and nematodes, play important roles in agriculture and in natural ecosystems. Some of these microbes cause devastating diseases that lead to $>40 \%$ yield losses on major crops (Fisher et al. 2012; Pennisi 2010) and therefore threaten global food security. To contain diseases caused by plant pathogens, farmers rely on multiple strategies including adaptation of cultural practices such as crop rotation, but also deployment of resistant crop varieties and the use of chemical control agents such as fungicides. Nevertheless, pathogens may evolve to rapidly overcome such control measures (McDonald and Linde 2002; Stukenbrock and McDonald 2008).

To establish a successful infection, plant pathogens need to overcome the plant immune system. Plant cells deploy extracellular and intracellular receptors to detect invasion patterns that indicate the presence or activity of pathogens to subsequently mount immune responses (Cook et al. 2015). In turn, pathogens secrete so-called effector proteins to deregulate these host responses (Cook et al. 2015; Rovenich et al. 2014). However, effectors themselves can become invasion patterns when they become recognized by plant immune receptors that trigger an immune response, leading to an incompatible interaction between the pathogen and the host (Cook et al. 2015). To avoid recognition by the plant immune system, pathogens in turn evolve novel effectors or modify or lose existing ones.

Plant pathogen genomes generally encode a plethora of effectors. Effector diversification is mediated by genomic mechanisms that range from single nucleotide polymorphisms to structural variations that can affect chromosomal shape and gene content (Dong et al. 2015; Raffaele and Kamoun 2012; Seidl and Thomma 2014). In the past, various methods have been used to identify effector repertoires, and to determine their diversity. Here, we discuss the recent progress in genomic-based methods for effector discovery, while focusing on effectors from plant pathogens with a biotrophic or hemibiotrophic lifestyle. Furthermore, we

Corresponding author: M. F. Seidl; E-mail address: michael.seidl@wur.nl

http://dx.doi.org/10.1094/PHYTO-02-16-0110-FI

(C) 2016 The American Phytopathological Society highlight how effector discovery can contribute to the development of resistance breeding strategies and disease management.

\section{GENOMICS-BASED EFFECTOR DISCOVERY}

More than a decade ago, the genome of the first plant-associated microbe, the plant-pathogenic bacterium Xylella fastidiosa, was sequenced (Simpson et al. 2000). Five years later, the rice blast fungus Magnaporthe oryzae was the first eukaryotic plant pathogen for which a genome sequence became available (Dean et al. 2005), soon followed by the genome sequences of two oomycete plant pathogens, Phytophthora sojae and P. ramorum (Tyler et al. 2006). All of these genomes were sequenced using Sanger sequencing, which is laborious, costly, and low in throughput (Kircher and Kelso 2010). Subsequent advances in high throughput sequencing technologies, termed next-generation sequencing (NGS), have allowed rapid sequencing of entire genomes at significantly reduced costs (Metzker 2010). This development also brought genomic sciences within reach of research laboratories that study nonmodel organisms. Consequently, the number of available genome sequences has increased exponentially. Whereas researchers were fortunate to have access to a genome sequence of their organism of interest a decade ago, by now the availability of genome sequences for a multitude of genotypes of the same species is becoming the standard. Phytopathologists are especially interested in population genomic data to determine core and lineage-specific effector repertoires of their pathogen of interest, allowing to investigate effector dynamics and evolution. However, reliable assessment of effector repertoires remains a considerable challenge.

Pathogens secrete effectors that exert their activity either in the host's extracellular environment (apoplastic effectors) or inside host cells (cytoplasmic effectors) (Giraldo and Valent 2013). Effectors are generally secreted via the endoplasmic reticulum ER/ Golgi route, which requires a hydrophobic N-terminal signal peptide (von Heijne 1990). To date, most experimentally verified fungal and oomycete effectors contain such an N-terminal secretion signal (Lo Presti et al. 2015; Stergiopoulos and de Wit 2009). Therefore, genome-wide studies aiming to identify effector candidates commonly first predict the secretome, i.e., the repertoire of all secreted 
proteins, by querying for the presence of $\mathrm{N}$-terminal signal peptides (Lo Presti et al. 2015).

Upon secretion into the extracellular space, effectors may subsequently be translocated into the host cytoplasm. In oomycetes, so far two distinct classes of cytoplasmic effectors have been described, the RXLRs and the Crinklers (CRNs). Both contain conserved amino acid motifs in the $\mathrm{N}$-terminal region downstream of the signal peptide, which have been proposed to facilitate host-cell translocation (Schornack et al. 2010; Whisson et al. 2007). RXLR effectors contain an RXLR motif that is often followed by a (D)EER motif, while CRNs contain an LXLFLAK motif (Haas et al. 2009; Torto et al. 2003; Whisson et al. 2007). The presence of these motifs can be identified using computational methods (Haas et al. 2009; Jiang et al. 2008).

Most fungal and oomycete effectors that have been functionally characterized to date are smaller than 300 amino acids with four or more cysteine residues (Stergiopoulos and de Wit 2009). Importantly, however, these characteristics cannot be used as criteria to identify effectors, as also well-characterized effectors often lack these properties (Lo Presti et al. 2015; Sperschneider et al. 2015a). Therefore, to exhaustingly describe effector repertoires of plant pathogens, universal features of effector candidates, which are their secretion and differential expression in planta, should be considered (Sperschneider et al. 2015a). Automatic classification methods that do not solely rely on strict rules can rank proteins according to their likelihood of being effectors by integrating multiple effector properties, e.g., protein size and cysteine content, and thus can further aid effector identification (Saunders et al. 2012). Recently, 'EffectorP' has been introduced which is the first program that utilizes machine learning to improve the prediction of fungal effector proteins from secretomes (Sperschneider et al. 2015b). 'EffectorP' uses sequence-derived features to predict fungal effectors from secretomes (Sperschneider et al. 2015b), thereby limiting the direct dependency on the above mentioned rules of effector selection. However, fungal effectors are a very heterogeneous group of proteins and, even though novel approaches such as 'EffectorP' hold promises in improving effector discovery, effector proteins remain notoriously difficult to predict.

Comparative genomics-based effector discovery. The availability of genome sequences of closely related pathogens, or of different strains of the same pathogenic species, permit comparative studies to identify effectors and to determine core and lineagespecific effector repertoires of the pathogen of interest, allowing to investigate effector dynamics and evolution. Genome comparisons of the closely related fungal maize pathogens Ustilago maydis and Sporisorium reilianum revealed 43 genomic regions with decreased sequence conservation, some of which were completely absent in one of the species (Schirawski et al. 2010). Notably, these divergent regions harbor in planta induced genes encoding secreted proteins, likely representing effectors (Kamper et al. 2006; Schirawski et al. 2010). Deletion analyses in these effector-rich regions confirmed their contribution to pathogen virulence (Kamper et al. 2006; Schirawski et al. 2010), thereby highlighting the merit of comparative genomics to flag genes as candidate effectors.

Comparisons between related pathogens can also provide insights into core and lineage-specific effector repertoires. For example, genome comparison of multiple strains of the vascular wilt pathogen Verticillium dahliae identified large lineage-specific genomic regions, which are regions that are only present in a subset of the $V$. dahliae population (de Jonge et al. 2013). These regions are enriched for secreted, in planta induced effector candidates that contribute to plant colonization (de Jonge et al. 2013). Genome comparisons of 65 geographically diverse strains of the cassava bacterial blight pathogen Xanthomonas axonopodis pv. manihotis revealed multiple lineage-specific effector candidates (Bart et al. 2012). Moreover, multiple effectors were found to be highly conserved and have been maintained throughout the world in all field samples (Bart et al. 2012).
Effector genes in plant pathogens such as Leptosphaeria maculans and Fusarium oxysporum can also be located on distinct chromosomes that are under specific conditions not required for growth, and therefore have been referred to as conditionally dispensable chromosomes (CDCs) (Balesdent et al. 2013; Ma et al. 2010). Comparisons between CDCs of related pathogens have been shown to facilitate effector discovery (Williams et al. 2016). For example, comparisons between CDCs from legumeinfecting Fusarium oxysporum f. sp. medicaginis with CDCs of F. oxysporum f. sp. pisi and F. oxysporum f. sp. ciceris revealed small conserved genomic regions that contain in planta expressed genes encoding secreted proteins, which likely represent conserved effectors with roles in pathogenicity on legume hosts (Williams et al. 2016).

\section{COMPARATIVE POPULATION GENOMICS- AND TRANSCRIPTOMICS-BASED DISCOVERY OF AVIRULENCE EFFECTOR GENES}

Genome comparisons can also be utilized to identify effectors that are recognized by the plant immune system, so called avirulence effectors. Here, comparisons of avirulent and virulent strains can lead to the identification of single nucleotide polymorphisms (SNPs) in the protein-coding regions of effectors or reveal presence/absence polymorphisms, i.e., genomic regions that are exclusive to avirulent or virulent strains. For example, comparative genomics of multiple virulent and avirulent $V$. dahliae strains uncovered a $50-\mathrm{kb}$ region encoding a single highly expressed effector gene that is present in avirulent strains but absent in virulent strains (de Jonge et al. 2012). This effector was subsequently experimentally shown to be the virulence factor Ave 1 that is recognized by Vel-carrying tomato plants (de Jonge et al. 2012). In the melon wilt fungus $F$. oxysporum f. sp. melonis, the effector AVRFOM2, which is recognized by melon Fom-2, was recently identified by comparative genomics of virulent and avirulent $F$. oxysporum f. sp. melonis strains (Schmidt et al. 2016). Similar to comparative analyses that exploit genome sequences, the sequencing and subsequent analyses of transcriptomes can lead to the identification of effectors. For example, combining in silico predictions with transcriptome comparisons of virulent and avirulent Cladosporium fulvum strains led to the identification of two polymorphic effector candidates, one of which was later confirmed to encode Avr5, which is recognized by the tomato immune receptor Cf5 (Mesarich et al. 2014).

\section{ERRONEOUS GENOME ASSEMBLY AND ANNOTATION HAMPER EFFECTOR DISCOVERY}

Nowadays, genome sequencing projects that utilize secondgeneration sequencing technologies generate millions of short $(<500 \mathrm{bp})$ sequence fragments, so-called reads, of relatively high quality ( 1 sequence error per $1 \mathrm{~kb}$ ) (Metzker 2010). However, the assembly of these reads into contiguous sequences, ideally chromosomes, is significantly hampered by highly similar repetitive sequences such as transposable elements (TEs). Sequencing reads that are shorter than repetitive sequences lead to their collapse, or to fragmented genome assemblies. Moreover, repetitive sequences in ascomycetes are often targeted by a genome-defense mechanism that induces specific $\mathrm{C}$ to $\mathrm{T}$ mutations, called repeat induced point mutations (RIP) (Selker 2002). RIP thereby locally elevates the AT content, which is a known bias for many second-generation technologies leading to low sequencing yields in these regions which further impact genome assemblies (Dohm et al. 2008). Notably, in many plant pathogens, effector genes reside in repeatrich genomic subcompartments where repeats facilitate rapid effector diversification by promoting structural variations (Dong et al. 2015; Raffaele and Kamoun 2012; Seidl and Thomma 2014). Moreover, effectors are often flanked by repetitive elements that 
can be targeted by RIP, which can lead to rapid effector gene diversification as demonstrated, for example, in L. maculans (Gout et al. 2007). Based on the limitations inherent to secondgeneration sequencing technologies, effector-rich regions are often not completely assembled, thereby hampering the complete and accurate identification of effector repertoires and their diversity (Fig. 1A) (Thomma et al. 2016).

Advances in sequencing technologies have opened possibilities to overcome the limitations of short-read sequencing leading to significant improvement in genome assemblies. Third-generation sequencing technologies such as single-molecule real-time (SMRT) and nanopore sequencing generate long sequencing reads $(>1 \mathrm{~kb})$ that can span entire repetitive sequences and therefore enable more contiguous genome assemblies (Ashton et al. 2015; Kim et al. 2014; Powers et al. 2013; Shin et al. 2013). However, reads from third generation sequencing platforms display a relatively high error rate $(\sim 15 \%)$. To correct these sequencing errors, two alternative approaches are commonly applied. Hybrid error corrections such as implemented in Nanocorr (Goodwin et al. 2015) or PacBio corrected reads $(\mathrm{PBcR})$ use high-quality short reads aligned to third generation long reads to correct for sequencing errors (Koren et al. 2012). Alternatively, errors in long reads can be faithfully corrected by consensus-based approaches such as provided by HGAP (Chin et al. 2013) or Nanocorrect (Loman et al. $2015)$, if sequencing is performed at considerable depth $(\geq 50 \times$ genomic coverage) (Faino et al. 2015). The costs involved in third-generation sequencing, in particular for large genomes, make this technology not yet widely adopted. Therefore, with the expected advances in sequencing technologies, i.e., longer reads with lower error rate and reduction in costs, sequencing and assembly of larger and complex (repeat-rich) genomes will become feasible. Sequence contiguity can be further increased by the application of optical mapping, which is a technique that constructs high-resolution restriction maps from a single DNA molecule (Levy-Sakin and Ebenstein 2013). Subsequently, the optical map is aligned to an in silico restriction map of the genome assembly, thereby facilitating the placement of assembled sequences into contiguous regions. This technology has been successfully applied for the genome assemblies of multiple plant pathogens such as Botrytis cinerea, F. oxysporum, P. infestans, and V. dahliae (Amselem et al. 2011; Haas et al. 2009; Klosterman et al. 2011; Ma et al. 2010). Recently, the combination of longread sequencing using SMRT sequencing technology and optical mapping yielded the complete and gapless genome assemblies of two V. dahliae strains (Faino et al. 2015). Significantly, comparison with previous genome assemblies revealed a threefold increase in repetitive elements $(\sim 12 \%)$ compared with previous estimate of $\sim 4 \%$ (de Jonge et al. 2013; Faino et al. 2015; Klosterman et al. 2011; Seidl et al. 2015), indicating that repeats in the previous genome assemblies have been under-represented. Therefore, complete genome assemblies mark a crucial step toward the optimal prediction of full effector repertoires in repeat-rich regions

Apart from fragmented genome assemblies, incorrect gene annotation can hamper effector discovery (Fig. 1B). Many of the previously annotated gene models in the fungal wheat pathogen Zymoseptoria tritici have incorrect exon/intron boundaries and about 735 lack either start or stop codons (H. A. Y. Gibriel, B. P. H. J. Thomma, and M. F. Seidl, unpublished data), which likely compromised the study of effectors candidates that had been selected based on these erroneous gene models (Mirzadi Gohari et al. 2015). Read data obtained from NGS-based RNA sequencing (RNA-seq) can be mapped to the reference genome, which provides a valuable guide for gene annotation as it reveals the exon-intron boundaries, and correct transcription start/stop sites (Fig. 1B) (Yandell and Ence 2012). To achieve a high-quality gene prediction, $a b$ initio or alignment-based gene predictions can be supplemented with RNA-seq data (Faino and Thomma 2014).
There has been a steady progress in the suite of gene-prediction tools that combine RNA-seq data with other lines of evidence including Maker2 (Holt and Yandell 2011), EVidenceModeler (EVM) (Haas et al. 2008), and BRAKER1 (Hoff et al. 2015). By combining ab initio gene predictions with RNA-seq supported data, the previous gene annotation of $Z$. tritici was recently reassessed, leading to the correction of 1,555 gene models (Grandaubert et al. 2015). Next to transcriptomics, also proteomics can be used to validate and correct gene annotation, in particular of those genes encoding secreted proteins. For example, a large-scale proteomic study aiming to profile the extracellular proteome of $P$. infestans validated the extracellular nature of 254 proteins previously predicted to be secreted (Meijer et al. 2014). Moreover, these analyses also led to the correction of about 150 open reading frames in the $P$. infestans genome that were previously incorrectly annotated (Meijer et al. 2014).

\section{USING EFFECTORS AS A TOOL TO SCREEN FOR DISEASE RESISTANCE}

Effector repertoires determined by genomics-based discoveries can be exploited to aid breeding for disease resistance. 'Effectoromics' is a large-scale screening approach that uses effector candidates to identify host resistance $(R)$ genes (Vleeshouwers et al. 2008). This approach is based on transient expression of candidate effectors in plant leaves, e.g., by agroinfiltration (Agrobacterium tumefaciens transient transformation assay) and/or a virus vector such as Potato virus $X$ (Vleeshouwers et al. 2008). Subsequently, plants are screened for the occurrence of hypersensitive cell death responses (HR), indicating the recognition of the effector by a matching plant immune receptor. 'Effectoromics' can contribute to resistance breeding by accelerating the identification of immune receptors when the matching effectors are available, as it replaces the slow process of generating stable transformants ( $\mathrm{Du}$ and Vleeshouwers 2014; Vleeshouwers et al. 2008).

Effectors can target genes that critically facilitate compatible interactions between pathogens and their hosts, and thus these targets have often been referred to as susceptibility genes (van Schie and Takken 2014). Previously, susceptibility genes were identified by screening plant germplasm for recessive resistance (Bai et al. 2005), or by induced mutations that confer loss-ofsusceptibility toward pathogens, which led to the identification of about 30 susceptibility genes (Gawehns et al. 2013). Alternatively, knowledge on the effector repertoire enables the usage of effectors as guides to identify plant susceptibility genes, for example by using protein-protein interaction assays such as yeast-two hybrid screening (Bos et al. 2010). Upon identification of a susceptibility gene, inactivation by subsequent mutations may confer disease resistance (Lewis et al. 2012), as this might interfere with the capability of the effectors to interact with their targets, and thereby limit the pathogen's ability to survive (Gawehns et al. 2013; van Schie and Takken 2014). Durability of resistance is a priority in plant breeding. One way to achieve durable resistance against plant pathogens is by incorporation of multiple immune receptor genes into a single cultivar (gene pyramiding) as these can detect multiple effectors of the same pathogen (Michelmore et al. 2013). However, breeding multiple immune receptor genes into a cultivar is a time-consuming process and requires a sufficient number of previously identified receptor genes (Michelmore et al. 2013). Alternatively, susceptibility genes can provide more durable resistance than deployment of immune receptors, as they are essential for pathogen survival (van Schie and Takken 2014). However, mutations in susceptibility genes often have pleiotropic effects such as dwarfism or sensitivity to other stresses, thereby limiting their utilization in agriculture (Gawehns et al. 2013).

Knowledge on effectors can also be used to develop protection strategies against pathogens, as silencing these effectors might lead to reduced pathogen development. Host-induced gene silencing 
(HIGS) is based on exploiting an RNA silencing mechanism to target a selected pathogen gene, for example an effector gene, via the host plant (Nowara et al. 2010). Plants can be transformed with hairpin RNA constructs that target selected pathogen effectors to suppress their expression. For example, HIGS in barley expressing dsRNA targeting the effector gene Avralo from the fungus Blumeria graminis led to reduced disease incidence (Nowara et al. 2010). To avoid pathogen evasion by loss of the targeted effector, conserved genes that are unlikely to be lost by the pathogen can be targeted. For example, HIGS in barley targeting the cytochrome P450 gene $C Y P 51$ of the wheat pathogen $F$. graminearum leads to complete plant immunity (Koch et al. 2013). Even though HIGS has the potential to become a powerful tool for disease control, its application requires the usage of genetically modified plants, which

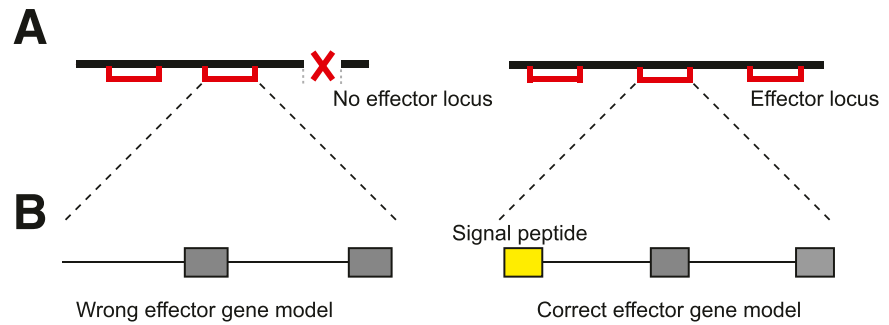

Fig. 1. Erroneous genome assembly and annotation hamper effector discovery. Correct effector repertoires are obtained with proper assembly and annotation. A, A stretch of DNA (black bar) that contains multiple effector genes (red blocks) is shown. In a fragmented genome assembly, an effector gene might be missing, as effectors are often located in repeat-rich regions. In gapless genome assemblies, all effector genes are present. B, Identification of effector genes in the predicted gene set is influenced by the quality of gene annotation. Applying effector selection criteria will miss or wrongly classify effector candidate in erroneous gene models that, e.g., miss the correct start/stop codon. Mining of correctly annotated gene models with correct start/stop codon and signal peptides will yield full effector repertoires. is restricted under current legislative and public consent in many countries worldwide.

\section{MONITORING PATHOGEN FIELD POPULATIONS TO ASSESS EFFECTOR DIVERSITY}

DNA and RNA sequencing technologies allow to monitor pathogen populations in fields, and thereby enable pathogen surveillance. For example, field transcriptome sequencing of Puccinia striiformis $\mathrm{f}$. sp. tritici-infected wheat revealed a dramatic shift in the pathogen population structure in the UK (Hubbard et al. 2015). Similarly, genome and transcriptome analysis of different strains of $P$. infestans provided insights into the emergence of the aggressive lineage 13_A2 in northwest Europe (Cooke et al. 2012). Genome sequencing enables researchers to rapidly assess effector diversity, which can indicate the emergence of new pathogens that have the potential to overcome host resistance in the field (Fig. 2). Therefore, monitoring of effector diversity, and subsequent deployment of plants carrying the matching resistance gene, would greatly contribute to disease management. The application of sequencing technologies to monitor pathogen migration and diversity will likely further accelerate in the future. Rapid, nearly real-time genome sequencing of pathogen populations can be applied on field isolates using the MiniION system, which is a portable sequencer that sequences individual DNA molecules using nanopore technology. MiniION can presently sequence bacterial and viral genomes in as little as $48 \mathrm{~h}$ (Check Hayden 2015; Quick et al. 2015; Quick et al. 2016). For example, MinION was used for realtime detection of Salmonella enterica from clinical isolates during a hospital outbreak, and yielded reliable clinical information in less than half a day (Quick et al. 2015). Similarly, during the 2015 Ebola virus outbreak in West Africa, real-time genomic sequencing revealed insights into virus diversity, and provided genomic information for epidemiological investigations to monitor disease dissemination (Quick et al. 2016). In the future, plant pathogen genomes can be rapidly sequenced with this device, disclosing

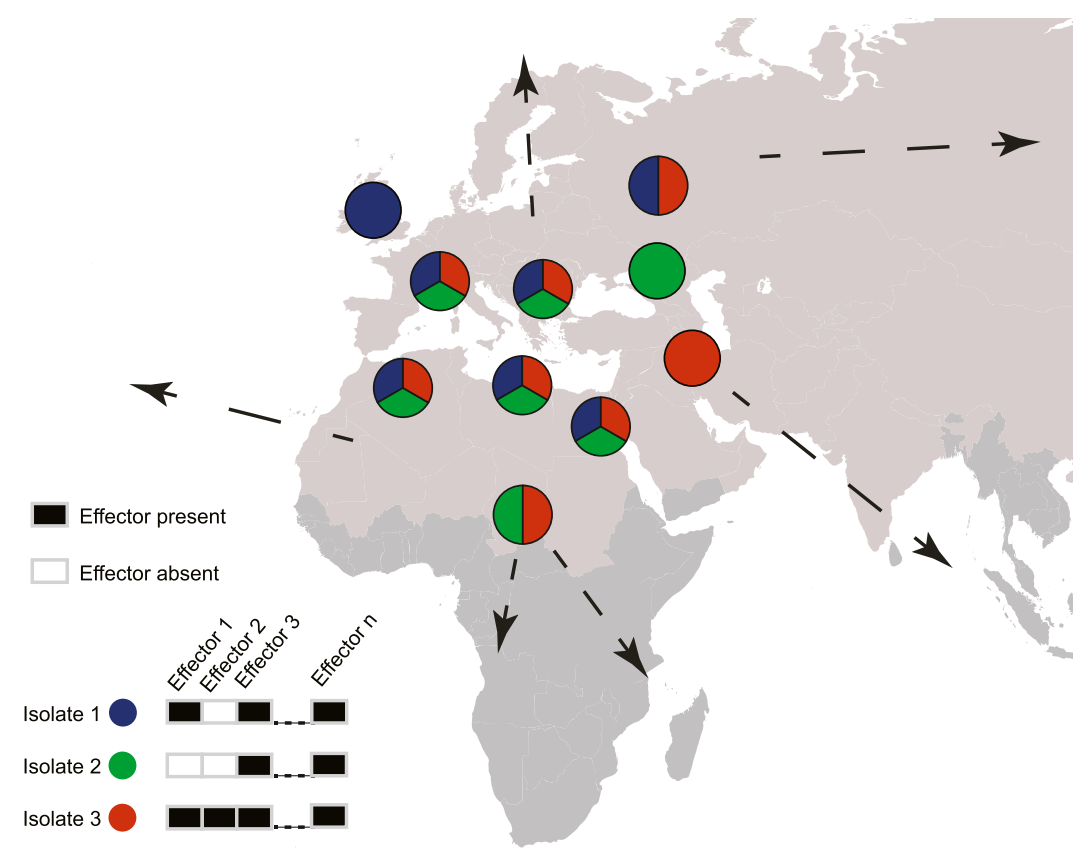

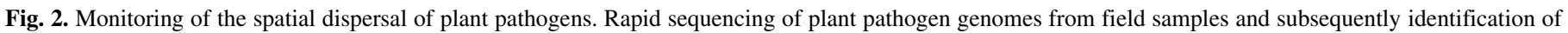

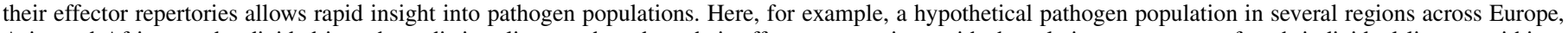

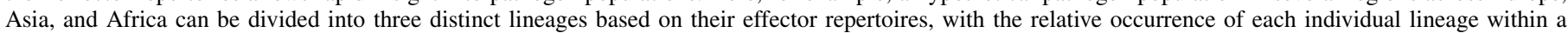

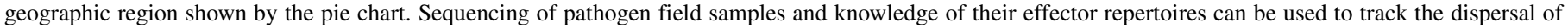
pathogen lineages into new geographic regions (arrows). 
information on their effectors repertoires. Further fueled by technological advances of the MinION platform, we anticipate that real-time disease monitoring by genome sequencing in agricultural settings will provide unprecedented opportunities to monitor the spread of plant pathogens, and will be a perquisite to install timely and suitable countermeasures.

\section{ACKNOWLEDGMENTS}

Work in the laboratory of B. P. H. J. Thomma is support by the Research Council Earth and Life Sciences (ALW) of the Netherlands Organization of Scientific Research (NWO). M. F. Seidl acknowledges the receipt of a VENI grant of ALW-NWO, project number 863.15.005.

\section{LITERATURE CITED}

Amselem, J., Cuomo, C. A., van Kan, J. A. L., Viaud, M., Benito, E. P., Couloux, A., Coutinho, P. M., de Vries, R. P., Dyer, P. S., Fillinger, S., Fournier, E., Gout, L., Hahn, M., Kohn, L., Lapalu, N., Plummer, K. M., Pradier, J.-M., Quévillon, E., Sharon, A., Simon, A., ten Have, A., Tudzynski, B., Tudzynski, P., Wincker, P., Andrew, M., Anthouard, V., Beever, R. E., Beffa, R., Benoit, I., Bouzid, O., Brault, B., Chen, Z., Choquer, M., Collémare, J., Cotton, P., Danchin, E. G., Da Silva, C., Gautier, A., Giraud, C., Giraud, T., Gonzalez, C., Grossetete, S., Güldener, U., Henrissat, B., Howlett, B. J., Kodira, C., Kretschmer, M., Lappartient, A., Leroch, M., Levis, C., Mauceli, E., Neuvéglise, C., Oeser, B., Pearson, M., Poulain, J., Poussereau, N., Quesneville, H., Rascle, C., Schumacher, J., Ségurens, B., Sexton, A., Silva, E., Sirven, C., Soanes, D. M., Talbot, N. J., Templeton, M., Yandava, C., Yarden, O., Zeng, Q., Rollins, J. A., Lebrun, M.-H., and Dickman, M. 2011. Genomic analysis of the necrotrophic fungal pathogens Sclerotinia sclerotiorum and Botrytis cinerea. PLoS Genet. 7:e1002230.

Ashton, P. M., Nair, S., Dallman, T., Rubino, S., Rabsch, W., Mwaigwisya, S., Wain, J., and O'Grady, J. 2015. MinION nanopore sequencing identifies the position and structure of a bacterial antibiotic resistance island. Nat. Biotechnol. 33:296-300.

Bai, Y., van der Hulst, R., Bonnema, G., Marcel, T. C., Meijer-Dekens, F., Niks, R. E., and Lindhout, P. 2005. Tomato defense to Oidium neolycopersici: Dominant $\mathrm{Ol}$ genes confer isolate-dependent resistance via a different mechanism than recessive ol-2. Mol. Plant-Microbe Interact. 18:354362.

Balesdent, M.-H., Fudal, I., Ollivier, B., Bally, P., Grandaubert, J., Eber, F., Chèvre, A.-M., Leflon, M., and Rouxel, T. 2013. The dispensable chromosome of Leptosphaeria maculans shelters an effector gene conferring avirulence towards Brassica rapa. New Phytol. 198:887-898.

Bart, R., Cohn, M., Kassen, A., McCallum, E. J., Shybut, M., Petriello, A., Krasileva, K., Dahlbeck, D., Medina, C., Alicai, T., Kumar, L., Moreira, L. M., Neto, J. R., Verdier, V., Santana, M. A., Kositcharoenkul, N., Vanderschuren, H., Gruissem, W., Bernal, A., and Staskawicz, B. J. 2012. High-throughput genomic sequencing of cassava bacterial blight strains identifies conserved effectors to target for durable resistance. Proc. Natl. Acad. Sci. USA 109:E1972-E1979.

Bos, J. I. B., Armstrong, M. R., Gilroy, E. M., Boevink, P. C., Hein, I., Taylor, R. M., Zhendong, T., Engelhardt, S., Vetukuri, R. R., Harrower, B., Dixelius, C., Bryan, G., Sadanandom, A., Whisson, S. C., Kamoun, S., and Birch, P. R. J. 2010. Phytophthora infestans effector AVR3a is essential for virulence and manipulates plant immunity by stabilizing host E3 ligase CMPG1. Proc. Natl. Acad. Sci. 107:9909-9914.

Check Hayden, E. 2015. Pint-sized DNA sequencer impresses first users. Nature 521:15-16.

Chin, C. S., Alexander, D. H., Marks, P., Klammer, A. A., Drake, J., Heiner, C., Clum, A., Copeland, A., Huddleston, J., Eichler, E. E., Turner, S. W., and Korlach, J. 2013. Nonhybrid, finished microbial genome assemblies from long-read SMRT sequencing data. Nat. Methods 10:563-569.

Cook, D. E., Mesarich, C. H., and Thomma, B. P. H. J. 2015. Understanding plant immunity as a surveillance system to detect invasion. Annu. Rev. Phytopathol. 53:541-563.

Cooke, D. E. L., Cano, L. M., Raffaele, S., Bain, R. A., Cooke, L. R., Etherington, G. J., Deahl, K. L., Farrer, R. A., Gilroy, E. M., Goss, E. M., Grünwald, N. J., Hein, I., MacLean, D., McNicol, J. W., Randall, E., Oliva, R. F., Pel, M. A., Shaw, D. S., Squires, J. N., Taylor, M. C., Vleeshouwers, V. G. A. A., Birch, P. R. J., Lees, A. K., and Kamoun, S. 2012. Genome analyses of an aggressive and invasive lineage of the Irish potato famine pathogen. PLoS Pathog. 8:e1002940.

de Jonge, R., Bolton, M. D., Kombrink, A., van den Berg, G. C. M., Yadeta, K. A., and Thomma, B. P. H. J. 2013. Extensive chromosomal reshuffling drives evolution of virulence in an asexual pathogen. Genome Res. 23: 1271-1282.

de Jonge, R., Peter van Esse, H., Maruthachalam, K., Bolton, M. D., Santhanam, P., Saber, M. K., Zhang, Z., Usami, T., Lievens, B., Subbarao, K. V., and Thomma, B. P. H. J. 2012. Tomato immune receptor Ve1 recognizes effector of multiple fungal pathogens uncovered by genome and RNA sequencing. Proc. Natl. Acad. Sci. 109:5110-5115.

Dean, R. A., Talbot, N. J., Ebbole, D. J., Farman, M. L., Mitchell, T. K., Orbach, M. J., Thon, M., Kulkarni, R., Xu, J.-R., Pan, H., Read, N. D., Lee, Y.-H., Carbone, I., Brown, D., Oh, Y. Y., Donofrio, N., Jeong, J. S., Soanes, D. M., Djonovic, S., Kolomiets, E., Rehmeyer, C., Li, W., Harding, M., Kim, S., Lebrun, M.-H., Bohnert, H., Coughlan, S., Butler, J., Calvo, S., Ma, L.-J., Nicol, R., Purcell, S., Nusbaum, C., Galagan, J. E., and Birren, B. W. 2005. The genome sequence of the rice blast fungus Magnaporthe grisea. Nature 434:980-986.

Dohm, J. C., Lottaz, C., Borodina, T., and Himmelbauer, H. 2008. Substantial biases in ultra-short read data sets from high-throughput DNA sequencing. Nucleic Acids Res. 36:e105.

Dong, S., Raffaele, S., and Kamoun, S. 2015. The two-speed genomes of filamentous pathogens: waltz with plants. Curr. Opin. Genet. Dev. 35:57-65.

Du, J., and Vleeshouwers, V. G. 2014. The do's and don'ts of effectoromics. Methods Mol. Biol. 1127:257-268.

Faino, L., Seidl, M. F., Datema, E., van den Berg, G. C. M., Janssen, A., Wittenberg, A. H. J., and Thomma, B. P. H. J. 2015. Single-molecule realtime sequencing combined with optical mapping yields completely finished fungal genome. MBio 6:e00936-15.

Faino, L., and Thomma, B. P. H. J. 2014. Get your high-quality low-cost genome sequence. Trends Plant Sci. 19:288-291.

Fisher, M. C., Henk, D. A., Briggs, C. J., Brownstein, J. S., Madoff, L. C., McCraw, S. L., and Gurr, S. J. 2012. Emerging fungal threats to animal, plant and ecosystem health. Nature 484:186-194.

Gawehns, F., Cornelissen, B. J. C., and Takken, F. L. W. 2013. The potential of effector-target genes in breeding for plant innate immunity. Microb. Biotechnol. 6:223-229.

Giraldo, M. C., and Valent, B. 2013. Filamentous plant pathogen effectors in action. Nat. Rev. Microbiol. 11:800-814.

Goodwin, S., Gurtowski, J., Ethe-Sayers, S., Deshpande, P., Schatz, M. C., and McCombie, W. R. 2015. Oxford Nanopore sequencing, hybrid error correction, and de novo assembly of a eukaryotic genome. Genome Res. 25:1750-1756.

Gout, L., Kuhn, M. L., Vincenot, L., Bernard-Samain, S., Cattolico, L., Barbetti, M., Moreno-Rico, O., Balesdent, M.-H., and Rouxel, T. 2007. Genome structure impacts molecular evolution at the AvrLm1 avirulence locus of the plant pathogen Leptosphaeria maculans. Environ. Microbiol. 9:2978-2992.

Grandaubert, J., Bhattacharyya, A., and Stukenbrock, E. H. 2015. RNA-seqbased gene annotation and comparative genomics of four fungal grass pathogens in the genus Zymoseptoria identify novel orphan genes and species-specific invasions of transposable elements. G3: Genes| Genomes| Genetics 5:1323-1333.

Haas, B. J., Kamoun, S., Zody, M. C., Jiang, R. H., Handsaker, R. E., Cano, L. M., Grabherr, M., Kodira, C. D., Raffaele, S., Torto-Alalibo, T., Bozkurt, T. O., Ah-Fong, A. M., Alvarado, L., Anderson, V. L., Armstrong, M. R., Avrova, A., Baxter, L., Beynon, J., Boevink, P. C., Bollmann, S. R., Bos, J. I., Bulone, V., Cai, G., Cakir, C., Carrington, J. C., Chawner, M., Conti, L., Costanzo, S., Ewan, R., Fahlgren, N., Fischbach, M. A., Fugelstad, J., Gilroy, E. M., Gnerre, S., Green, P. J., Grenville-Briggs, L. J., Griffith, J., Grunwald, N. J., Horn, K., Horner, N. R., Hu, C. H., Huitema, E., Jeong, D. H., Jones, A. M., Jones, J. D., Jones, R. W., Karlsson, E. K., Kunjeti, S. G., Lamour, K., Liu, Z., Ma, L., Maclean, D., Chibucos, M. C., McDonald, H., McWalters, J., Meijer, H. J., Morgan, W., Morris, P. F., Munro, C. A., O’Neill, K., Ospina-Giraldo, M., Pinzon, A., Pritchard, L., Ramsahoye, B., Ren, Q., Restrepo, S., Roy, S., Sadanandom, A., Savidor, A., Schornack, S., Schwartz, D. C., Schumann, U. D., Schwessinger, B., Seyer, L., Sharpe, T., Silvar, C., Song, J., Studholme, D. J., Sykes, S., Thines, M., van de Vondervoort, P. J., Phuntumart, V., Wawra, S., Weide, R., Win, J., Young, C., Zhou, S., Fry, W., Meyers, B. C., van West, P., Ristaino, J., Govers, F., Birch, P. R., Whisson, S. C., Judelson, H. S., and Nusbaum, C. 2009. Genome sequence and analysis of the Irish potato famine pathogen Phytophthora infestans. Nature 461:393-398.

Haas, B. J., Salzberg, S. L., Zhu, W., Pertea, M., Allen, J. E., Orvis, J., White, O., Buell, C. R., and Wortman, J. R. 2008. Automated eukaryotic gene structure annotation using EVidenceModeler and the Program to Assemble Spliced Alignments. Genome Biol. 9:R7.

Hoff, K. J., Lange, S., Lomsadze, A., Borodovsky, M., and Stanke, M. 2015. BRAKER1: Unsupervised RNA-Seq-based genome annotation with GeneMarkET and AUGUSTUS. Bioinformatics 32:767-769.

Holt, C., and Yandell, M. 2011. MAKER2: An annotation pipeline and genome-database management tool for second-generation genome projects. BMC Bioinformatics 12:491. 
Hubbard, A., Lewis, C., Yoshida, K., Ramirez-Gonzalez, R., de Vallavieille-Pope, C., Thomas, J., Kamoun, S., Bayles, R., Uauy, C., and Saunders, D. 2015. Field pathogenomics reveals the emergence of a diverse wheat yellow rust population. Genome Biol. 16:23.

Jiang, R. H. Y., Tripathy, S., Govers, F., and Tyler, B. M. 2008. RXLR effector reservoir in two Phytophthora species is dominated by a single rapidly evolving superfamily with more than 700 members. Proc. Natl. Acad. Sci. 105:4874-4879.

Kamper, J., Kahmann, R., Bolker, M., Ma, L.-J., Brefort, T., Saville, B. J., Banuett, F., Kronstad, J. W., Gold, S. E., Muller, O., Perlin, M. H., Wosten, H. A. B., de Vries, R., Ruiz-Herrera, J., Reynaga-Pena, C. G., Snetselaar, K., McCann, M., Perez-Martin, J., Feldbrugge, M., Basse, C. W., Steinberg, G., Ibeas, J. I., Holloman, W., Guzman, P., Farman, M., Stajich, J. E., Sentandreu, R., Gonzalez-Prieto, J. M., Kennell, J. C., Molina, L., Schirawski, J., Mendoza-Mendoza, A., Greilinger, D., Munch, K., Rossel, N., Scherer, M., Vranes, M., Ladendorf, O., Vincon, V., Fuchs, U., Sandrock, B., Meng, S., Ho, E. C. H., Cahill, M. J., Boyce, K. J., Klose, J., Klosterman, S. J., Deelstra, H. J., Ortiz-Castellanos, L., Li, W., Sanchez-Alonso, P., Schreier, P. H., Hauser-Hahn, I., Vaupel, M., Koopmann, E., Friedrich, G., Voss, H., Schluter, T., Margolis, J., Platt, D., Swimmer, C., Gnirke, A., Chen, F., Vysotskaia, V., Mannhaupt, G., Guldener, U., Munsterkotter, M., Haase, D., Oesterheld, M., Mewes, H.-W., Mauceli, E. W., DeCaprio, D., Wade, C. M., Butler, J., Young, S., Jaffe, D. B., Calvo, S., Nusbaum, C., Galagan, J., and Birren, B. W. 2006. Insights from the genome of the biotrophic fungal plant pathogen Ustilago maydis. Nature 444:97-101.

Kim, K. E., Peluso, P., Babayan, P., Yeadon, P. J., Yu, C., Fisher, W. W., Chin, C.-S., Rapicavoli, N. A., Rank, D. R., Li, J., Catcheside, D. E. A., Celniker, S. E., Phillippy, A. M., Bergman, C. M., and Landolin, J. M. 2014. Longread, whole-genome shotgun sequence data for five model organisms. Sci. Data 1:140045.

Kircher, M., and Kelso, J. 2010. High-throughput DNA sequencing-Concepts and limitations. BioEssays 32:524-536.

Klosterman, S. J., Subbarao, K. V., Kang, S., Veronese, P., Gold, S. E., Thomma, B. P., Chen, Z., Henrissat, B., Lee, Y. H., Park, J., Garcia-Pedrajas, M. D., Barbara, D. J., Anchieta, A., de Jonge, R., Santhanam, P., Maruthachalam, K., Atallah, Z., Amyotte, S. G., Paz, Z., Inderbitzin, P., Hayes, R. J., Heiman, D. I., Young, S., Zeng, Q., Engels, R., Galagan, J., Cuomo, C. A., Dobinson, K. F., and Ma, L. J. 2011. Comparative genomics yields insights into niche adaptation of plant vascular wilt pathogens. PLoS Pathog. 7:e1002137.

Koch, A., Kumar, N., Weber, L., Keller, H., Imani, J., and Kogel, K.-H. 2013. Host-induced gene silencing of cytochrome P450 lanosterol C14 $\alpha$ demethylase-encoding genes confers strong resistance to Fusarium species. Proc. Natl. Acad. Sci. 110:19324-19329.

Koren, S., Schatz, M. C., Walenz, B. P., Martin, J., Howard, J. T., Ganapathy, G., Wang, Z., Rasko, D. A., McCombie, W. R., Jarvis, E. D., and Phillippy, A. M. 2012. Hybrid error correction and de novo assembly of singlemolecule sequencing reads. Nat. Biotechnol. 30:693-700.

Levy-Sakin, M., and Ebenstein, Y. 2013. Beyond sequencing: Optical mapping of DNA in the age of nanotechnology and nanoscopy. Curr. Opin. Biotechnol. 24:690-698.

Lewis, J. D., Wan, J., Ford, R., Gong, Y., Fung, P., Nahal, H., Wang, P. W., Desveaux, D., and Guttman, D. S. 2012. Quantitative interactor screening with next-generation sequencing (QIS-Seq) identifies Arabidopsis thaliana MLO2 as a target of the Pseudomonas syringae type III effector HopZ2. BMC Genomics 13:8.

Lo Presti, L., Lanver, D., Schweizer, G., Tanaka, S., Liang, L., Tollot, M., Zuccaro, A., Reissmann, S., and Kahmann, R. 2015. Fungal effectors and plant susceptibility. Annu. Rev. Plant Biol. 66:513-545.

Loman, N. J., Quick, J., and Simpson, J. T. 2015. A complete bacterial genome assembled de novo using only nanopore sequencing data. Nat. Methods 12: 733-735.

Ma, L.-J., van der Does, H. C., Borkovich, K. A., Coleman, J. J., Daboussi, M.-J., Di Pietro, A., Dufresne, M., Freitag, M., Grabherr, M., Henrissat, B., Houterman, P. M., Kang, S., Shim, W.-B., Woloshuk, C., Xie, X., Xu, J.-R., Antoniw, J., Baker, S. E., Bluhm, B. H., Breakspear, A., Brown, D. W., Butchko, R. A. E., Chapman, S., Coulson, R., Coutinho, P. M., Danchin, E. G. J., Diener, A., Gale, L. R., Gardiner, D. M., Goff, S., Hammond-Kosack, K. E., Hilburn, K., Hua-Van, A., Jonkers, W., Kazan, K., Kodira, C. D., Koehrsen, M., Kumar, L., Lee, Y.-H., Li, L., Manners, J. M., Miranda-Saavedra, D., Mukherjee, M., Park, G., Park, J., Park, S.-Y., Proctor, R. H., Regev, A., Ruiz-Roldan, M. C., Sain, D., Sakthikumar, S., Sykes, S., Schwartz, D. C., Turgeon, B. G., Wapinski, I., Yoder, O., Young, S., Zeng, Q., Zhou, S., Galagan, J., Cuomo, C. A., Kistler, H. C., and Rep, M. 2010. Comparative genomics reveals mobile pathogenicity chromosomes in Fusarium. Nature 464:367-373.

McDonald, B. A., and Linde, C. 2002. Pathogen population genetics, evolutionary potential, and durable resistance. Annu. Rev. Phytopathol. 40: 349-379.
Meijer, H. J. G., Mancuso, F. M., Espadas, G., Seidl, M. F., Chiva, C., Govers, F., and Sabidó, E. 2014. Profiling the secretome and extracellular proteome of the potato late blight pathogen Phytophthora infestans. Mol. Cell. Proteomics 13:2101-2113.

Mesarich, C. H., Griffiths, S. A., van der Burgt, A., Ökmen, B., Beenen, H. G., Etalo, D. W., Joosten, M. H. A. J., and de Wit, P. J. G. M. 2014. Transcriptome sequencing uncovers the Avr5 avirulence gene of the tomato leaf mold pathogen Cladosporium fulvum. Mol. Plant-Microbe Interact. 27: 846-857.

Metzker, M. L. 2010. Sequencing technologies-The next generation. Nat. Rev. Genet. 11:31-46.

Michelmore, R. W., Christopoulou, M., and Caldwell, K. S. 2013. Impacts of resistance gene genetics, function, and evolution on a durable future. Annu. Rev. Phytopathol. 51:291-319.

Mirzadi Gohari, A., Ware, S. B., Wittenberg, A. H. J., Mehrabi, R., Ben M'Barek, S., Verstappen, E. C. P., van der Lee, T. A. J., Robert, O., Schouten, H. J., de Wit, P. P. J. G. M., and Kema, G. H. J. 2015. Effector discovery in the fungal wheat pathogen Zymoseptoria tritici. Mol. Plant Pathol. 16:931-945.

Nowara, D., Gay, A., Lacomme, C., Shaw, J., Ridout, C., Douchkov, D., Hensel, G., Kumlehn, J., and Schweizer, P. 2010. HIGS: Host-induced gene silencing in the obligate biotrophic fungal pathogen Blumeria graminis. Plant Cell 22:3130-3141.

Pennisi, E. 2010. Armed and dangerous. Science 327:804-805.

Powers, J. G., Weigman, V. J., Shu, J., Pufky, J. M., Cox, D., and Hurban, P. 2013. Efficient and accurate whole genome assembly and methylome profiling of E. coli. BMC Genomics 14:675.

Quick, J., Ashton, P., Calus, S., Chatt, C., Gossain, S., Hawker, J., Nair, S., Neal, K., Nye, K., Peters, T., De Pinna, E., Robinson, E., Struthers, K., Webber, M., Catto, A., Dallman, T., Hawkey, P., and Loman, N. 2015. Rapid draft sequencing and real-time nanopore sequencing in a hospital outbreak of Salmonella. Genome Biol. 16:114.

Quick, J., Loman, N. J., Duraffour, S., Simpson, J. T., Severi, E., Cowley, L., Bore, J. A., Koundouno, R., Dudas, G., Mikhail, A., Ouédraogo, N., Afrough, B., Bah, A., Baum, J. H. J., Becker-Ziaja, B., Boettcher, J. P., Cabeza-Cabrerizo, M., Camino-Sánchez, Á., Carter, L. L., Doerrbecker, J., Enkirch, T., Dorival, I. G., Hetzelt, N., Hinzmann, J., Holm, T., Kafetzopoulou, L. E., Koropogui, M., Kosgey, A., Kuisma, E., Logue, C. H., Mazzarelli, A., Meisel, S., Mertens, M., Michel, J., Ngabo, D., Nitzsche, K., Pallasch, E., Patrono, L. V., Portmann, J., Repits, J. G., Rickett, N. Y., Sachse, A., Singethan, K., Vitoriano, I., Yemanaberhan, R. L., Zekeng, E. G., Racine, T., Bello, A., Sall, A. A., Faye, O., Faye, O., Magassouba, N. F., Williams, C. V., Amburgey, V., Winona, L., Davis, E., Gerlach, J., Washington, F., Monteil, V., Jourdain, M., Bererd, M., Camara, A., Somlare, H., Camara, A., Gerard, M., Bado, G., Baillet, B., Delaune, D., Nebie, K. Y., Diarra, A., Savane, Y., Pallawo, R. B., Gutierrez, G. J., Milhano, N., Roger, I., Williams, C. J., Yattara, F., Lewandowski, K., Taylor, J., Rachwal, P., Turner, D. J., Pollakis, G., Hiscox, J. A., Matthews, D. A., Shea, M. K. O., Johnston, A. M., Wilson, D., Hutley, E., Smit, E., Di Caro, A., Wölfel, R., Stoecker, K., Fleischmann, E., Gabriel, M., Weller, S. A., Koivogui, L., Diallo, B., Keita, S., Rambaut, A., Formenty, P., Günther, S., and Carroll, M. W. 2016. Real-time, portable genome sequencing for Ebola surveillance. Nature 530:228-232.

Raffaele, S., and Kamoun, S. 2012. Genome evolution in filamentous plant pathogens: Why bigger can be better. Nat. Rev. Microbiol. 10:417-430.

Rovenich, H., Boshoven, J. C., and Thomma, B. P. H. J. 2014. Filamentous pathogen effector functions: Of pathogens, hosts and microbiomes. Curr. Opin. Plant Biol. 20:96-103.

Saunders, D. G. O., Win, J., Cano, L. M., Szabo, L. J., Kamoun, S., and Raffaele, S. 2012. Using hierarchical clustering of secreted protein families to classify and rank candidate effectors of rust fungi. PLoS One 7:e29847.

Schirawski, J., Mannhaupt, G., Munch, K., Brefort, T., Schipper, K., Doehlemann, G., Di Stasio, M., Rossel, N., Mendoza-Mendoza, A., Pester, D., Muller, O., Winterberg, B., Meyer, E., Ghareeb, H., Wollenberg, T., Munsterkotter, M., Wong, P., Walter, M., Stukenbrock, E., Guldener, U., and Kahmann, R. 2010. Pathogenicity determinants in smut fungi revealed by genome comparison. Science 330:1546-1548.

Schmidt, S. M., Lukasiewicz, J., Farrer, R., van Dam, P., Bertoldo, C., and Rep, M. C. 2016. Comparative genomics of Fusarium oxysporum f. sp. melonis reveals the secreted protein recognized by the Fom-2 resistance gene in melon. New Phytol. 209:307-318.

Schornack, S., van Damme, M., Bozkurt, T. O., Cano, L. M., Smoker, M., Thines, M., Gaulin, E., Kamoun, S., and Huitema, E. 2010. Ancient class of translocated oomycete effectors targets the host nucleus. Proc. Natl. Acad. Sci. 107:17421-17426.

Seidl, M. F., Faino, L., Shi-Kunne, X., van den Berg, G. C., Bolton, M. D., and Thomma, B. P. 2015. The genome of the saprophytic fungus Verticillium tricorpus reveals a complex effector repertoire resembling that of its pathogenic relatives. Mol. Plant-Microbe Interact. 28:362-373. 
Seidl, M. F., and Thomma, B. P. H. J. 2014. Sex or no sex: Evolutionary adaptation occurs regardless. BioEssays 36:335-345.

Selker, E. U. 2002. Repeat-induced gene silencing in fungi. Adv. Genet. 46: 439-450.

Shin, S. C., Ahn, D. H., Kim, S. J., Lee, H., Oh, T.-J., Lee, J. E., and Park, H. 2013. Advantages of single-molecule real-time sequencing in high-GC content genomes. PLoS One 8:e68824.

Simpson, A. J., Reinach, F. C., Arruda, P., Abreu, F. A., Acencio, M., Alvarenga, R., Alves, L. M., Araya, J. E., Baia, G. S., Baptista, C. S., Barros, M. H., Bonaccorsi, E. D., Bordin, S., Bove, J. M., Briones, M. R., Bueno, M. R., Camargo, A. A., Camargo, L. E., Carraro, D. M., Carrer, H., Colauto, N. B., Colombo, C., Costa, F. F., Costa, M. C., Costa-Neto, C. M., Coutinho, L. L., Cristofani, M., Dias-Neto, E., Docena, C., El-Dorry, H., Facincani, A. P., Ferreira, A. J., Ferreira, V. C., Ferro, J. A., Fraga, J. S., Franca, S. C., Franco, M. C., Frohme, M., Furlan, L. R., Garnier, M., Goldman, G. H., Goldman, M. H., Gomes, S. L., Gruber, A., Ho, P. L., Hoheisel, J. D., Junqueira, M. L., Kemper, E. L., Kitajima, J. P., Krieger, J. E., Kuramae, E. E., Laigret, F., Lambais, M. R., Leite, L. C., Lemos, E. G., Lemos, M. V., Lopes, S. A., Lopes, C. R., Machado, J. A., Machado, M. A., Madeira, A. M., Madeira, H. M., Marino, C. L., Marques, M. V., Martins, E. A., Martins, E. M., Matsukuma, A. Y., Menck, C. F., Miracca, E. C., Miyaki, C. Y., Monteriro-Vitorello, C. B., Moon, D. H., Nagai, M. A., Nascimento, A. L., Netto, L. E., Nhani, A., Jr., Nobrega, F. G., Nunes, L. R., Oliveira, M. A., de Oliveira, M. C., de Oliveira, R. C., Palmieri, D. A., Paris, A., Peixoto, B. R., Pereira, G. A., Pereira, H. A., Jr., Pesquero, J. B., Quaggio, R. B., Roberto, P. G., Rodrigues, V., M. de Rosa, A. J., de Rosa, V. E., Jr., de Sa, R. G., Santelli, R. V., Sawasaki, H. E., da Silva, A. C., da Silva, A. M., da Silva, F. R., da Silva, W. A., Jr., da Silveira, J. F., Silvestri, M. L., Siqueira, W. J., de Souza, A. A., de Souza, A. P., Terenzi, M. F., Truffi, D., Tsai, S. M., Tsuhako, M. H., Vallada, H., Van Sluys, M. A., Verjovski-Almeida, S., Vettore, A. L., Zago, M. A., Zatz, M., Meidanis, J., and Setubal, J. C. 2000. The genome sequence of the plant pathogen Xylella fastidiosa. The Xylella fastidiosa consortium of the organization for nucleotide sequencing and analysis. Nature 406:151-157.

Sperschneider, J., Dodds, P. N., Gardiner, D. M., Manners, J. M., Singh, K. B., and Taylor, J. M. 2015a. Advances and challenges in computational prediction of effectors from plant pathogenic fungi. PLoS Pathog. 11:e1004806.

Sperschneider, J., Gardiner, D. M., Dodds, P. N., Tini, F., Covarelli, L., Singh, K. B., Manners, J. M., and Taylor, J. M. 2015b. EffectorP: Predicting fungal effector proteins from secretomes using machine learning. New Phytol. 210:743-761.

Stergiopoulos, I., and de Wit, P. 2009. Fungal effector proteins. Annu. Rev. Phytopathol. 47:233-263.
Stukenbrock, E. H., and McDonald, B. A. 2008. The origins of plant pathogens in agro-ecosystems. Annu. Rev. Phytopathol. 46:75-100.

Thomma, B. P., Seidl, M. F., Shi-Kunne, X., Cook, D. E., Bolton, M. D., van Kan, J. A., and Faino, L. 2016. Mind the gap; seven reasons to close fragmented genome assemblies. Fungal Genet. Biol. 90:24-30.

Torto, T. A., Li, S., Styer, A., Huitema, E., Testa, A., Gow, N. A., van West, P., and Kamoun, S. 2003. EST mining and functional expression assays identify extracellular effector proteins from the plant pathogen Phytophthora. Genome Res. 13:1675-1685.

Tyler, B. M., Tripathy, S., Zhang, X., Dehal, P., Jiang, R. H., Aerts, A., Arredondo, F. D., Baxter, L., Bensasson, D., Beynon, J. L., Chapman, J., Damasceno, C. M., Dorrance, A. E., Dou, D., Dickerman, A. W., Dubchak, I. L., Garbelotto, M., Gijzen, M., Gordon, S. G., Govers, F., Grunwald, N. J., Huang, W., Ivors, K. L., Jones, R. W., Kamoun, S., Krampis, K., Lamour, K. H., Lee, M. K., McDonald, W. H., Medina, M., Meijer, H. J., Nordberg, E. K., Maclean, D. J., Ospina-Giraldo, M. D., Morris, P. F., Phuntumart, V., Putnam, N. H., Rash, S., Rose, J. K., Sakihama, Y., Salamov, A. A., Savidor, A., Scheuring, C. F., Smith, B. M., Sobral, B. W., Terry, A., Torto-Alalibo, T. A., Win, J., Xu, Z., Zhang, H., Grigoriev, I. V., Rokhsar, D. S., and Boore, J. L. 2006. Phytophthora genome sequences uncover evolutionary origins and mechanisms of pathogenesis. Science 313:1261-1266.

van Schie, C. C., and Takken, F. L. 2014. Susceptibility genes 101: How to be a good host. Annu. Rev. Phytopathol. 52:551-581.

Vleeshouwers, V. G. A. A., Rietman, H., Krenek, P., Champouret, N., Young, C., Oh, S.-K., Wang, M., Bouwmeester, K., Vosman, B., Visser, R. G. F., Jacobsen, E., Govers, F., Kamoun, S., and Van der Vossen, E. A. G. 2008. Effector genomics accelerates discovery and functional profiling of potato disease resistance and Phytophthora Infestans avirulence genes. PLoS One 3:e2875.

von Heijne, G. 1990. The signal peptide. J. Membr. Biol. 115:195-201.

Whisson, S. C., Boevink, P. C., Moleleki, L., Avrova, A. O., Morales, J. G., Gilroy, E. M., Armstrong, M. R., Grouffaud, S., van West, P., Chapman, S., Hein, I., Toth, I. K., Pritchard, L., and Birch, P. R. J. 2007. A translocation signal for delivery of oomycete effector proteins into host plant cells. Nature 450:115-118.

Williams, A. H., Sharma, M., Thatcher, L. F., Azam, S., Hane, J. K., Sperschneider, J., Kidd, B. N., Anderson, J. P., Ghosh, R., Garg, G., Lichtenzveig, J., Kistler, H. C., Shea, T., Young, S., Buck, S.-A. G., Kamphuis, L. G., Saxena, R., Pande, S., Ma, L.-J., Varshney, R. K., and Singh, K. B. 2016. Comparative genomics and prediction of conditionally dispensable sequences in legume-infecting Fusarium oxysporum formae speciales facilitates identification of candidate effectors. BMC Genomics 17:1-24.

Yandell, M., and Ence, D. 2012. A beginner's guide to eukaryotic genome annotation. Nat. Rev. Genet. 13:329-342. 